\title{
Achieving the Polyprofessionality of the Future Personnel Through the Development of Entrepreneurial Competencies
}

\author{
G. V. Tokareva \\ Department of Economic Theory and \\ Economics of agribusiness \\ Stavropol State Agrarian University \\ Stavropol, Russia \\ tokarewagalia@yandex.ru \\ A.A. Lezhebokov \\ Department of Sociology \\ North-Caucasus Federal University \\ Stavropol, Russia \\ lezhebokov.a@inbox.ru
}

\author{
E.V. Skiperskaya \\ Department of Economic Theory and Economics of \\ Agro-Industrial Complex \\ Stavropol State Agrarian University \\ Stavropol, Russia \\ skiperskaja@mail.ru \\ A.R. Baicherova \\ Department of Entrepreneurship and World Economy \\ Stavropol State Agrarian University \\ Stavropol, Russia \\ corsta@mail.ru
}

\author{
T.A. Zolotareva \\ Department social Philosophy and Ethnology \\ North-Caucasus Federal University \\ Stavropol, Russia \\ ethnos@stavsu.ru
}

\begin{abstract}
The article is devoted to the study of modern approaches to achieving the polyprofessionality of the personnel. We showed the relevance of the research question and highlighted a promising solution direction - the development of entrepreneurial competencies. The analysis is based on the documentary sources, discussions in publications of the world scientific community. The optimal combination of entrepreneurial and technological competencies of employees positively affects the development of innovative products of the enterprise and increases their stability under the conditions of uncertainty. Entrepreneurial competencies are important for employees and managers of social organizations and the public sector. In teaching entrepreneurship, an important additional effect is observed: entrepreneurial competence has a significant impact on the formation of positive psychological capital for graduates of educational programs and successful teamwork in the organization. We identified the directions for improving educational practices in the formation of entrepreneurial competencies: expanding the gamification of educational activities; increasing student satisfaction with their teacher; optimization of the structure of game modules; the approximation of the content of the game to the real regional socio-economic conditions; increasing the educational motivation of project participants. The mentioned areas of improvement will make it possible at the instrumental level to increase the efficiency of forming entrepreneurial competencies in order to achieve the polyprofessionality of the future personnel.
\end{abstract}

Keywords - polyprofessionality, personnel of the future, entrepreneurial competencies, youth entrepreneurship

\section{INTRODUCTION}

Today we are witnessing radical changes in all spheres of society. This is due to the new technological revolution, which is introducing a qualitative change in the way of doing business, based on the mass application of technological solutions. Numerous studies show that advanced technologies will spread very quickly and will have a systemic worldwide impact on the configuration and volume of markets. This trend is expected to be fully realized within the next 10-15 years [14]. These changes will affect the labor market. The development of fundamentally new high-tech industries and the deep technological modernization of traditional industries will lead both to the release of labor and new competency requirements for employment. One of the promising trends in the process of developing a model of the future employee is the consistency of knowledge simultaneously in related professional fields.

In this regard, the issue of ways to achieve the polyprofessionality of the future employee is becoming relevant. The basis of the polyprofessionalism of the future employee is a functional system of interaction between various branches of professional activity.

Today a significant number of positive practices have been accumulated to achieve the polyprofessionality of the staff of the future through the development of entrepreneurial competencies. It generally meets the strategic issues of employment at the stage of structural transformations in the economy and social sphere. 
The implementation of educational practices of youth entrepreneurship (as part of a modular approach in higher education and continuing professional education programs) is widely represented in the activities of supporting, federal, and industry-specific universities.

\section{METHODS AND MATERIALS}

Monitoring the effectiveness of activities aimed at promoting the development of youth entrepreneurship was carried out in order to study the level of participants' satisfaction with the quality of implementation of program activities.

Evaluation of the quality of the program activities' implementation was carried out by two methods: automated, through a federal Internet resource; collection and processing of primary data among students - project participants from the Stavropol Territory.

Monitoring the satisfaction of participants with the quality of the implementation of the stage "Implementation of game, training and other projects, educational courses, competitions among high school students aged 14-17 years" was carried out by the questionnaire method. The monitoring used 9 indicators of the quality of the measures taken, which are interpreted in the questions of the questionnaire: structured information; applicability of new skills; teacher's work; event organization; the level of accessibility of information on the implementation of the activities of the "You are an Entrepreneur" program; the quality of the event within the framework of the program; the general level of organization of the program events that you attended; the quality of the coaching (expert) composition of events; satisfaction from the information, knowledge gained in the framework of the implementation of the "You are an Entrepreneur" program.

The assessment was carried out by program participants on a five-point scale, where 5 points - students are completely satisfied and 1 point - absolutely not satisfied. Respondents had the opportunity to put any values in the specified range.

The object of monitoring is the participants of the "You are an Entrepreneur" program.

The subject is the satisfaction of participants with the quality of gaming, training and other projects, educational courses, contests that were implemented as part of the "You are an Entrepreneur" program.

The goal is to determine the level of general satisfaction of the participants of the "You are an Entrepreneur" program and the level of satisfaction in segmentation according to evaluation criteria, consisting of 9 indicators of the quality of activities.

In total, the participants in the events of the stage were 325 people.

\section{RESULTS}

The results of the assessment by students provided in the framework of game, training and other projects, educational courses, competitions of the "You are an Entrepreneur" program for students of 14-17 years old showed that with a maximum possible score of 5 points, the average score for the surveyed population was 4,5 points.

The analysis of the students' assessments of the applicability of new skills obtained as part of the training activities of the program showed that with a maximum possible score of 5 points, the average score for the surveyed population was 4.0 points.

The study of the level of satisfaction of the program participants with the work of teachers showed that with a maximum possible score of 5 points, the average score for the surveyed population was 4.7 points.

The analysis of the results of the students' assessment of the quality of the organization of events showed that with a maximum possible score of 5 points, the average score for the surveyed population was 4.9 points.

Satisfaction with the level of availability of information on the implementation of the activities of the program "You are an Entrepreneur" amounted to 4.8 points.

The analysis of the results of the students' assessment of the quality of the events showed that with a maximum possible score of 5 points, the average score for the surveyed population was 4.8 points.

Satisfaction with the general level of organization of events under the "You are an Entrepreneur" program was 4.8 points.

The analysis of the results of students' assessment of the quality of the coaching staff of the activities under the "You are an Entrepreneur" program showed that with a maximum possible score of 5 points, the average score for the surveyed population was 4.8 points.

The analysis of the results of the students 'satisfaction with the information and knowledge acquired in the framework of the "You are an Entrepreneur" program showed that with a maximum possible score of 5 points, the average score for the surveyed population was 4.7 points.

With the maximum possible score of 5 points, the average value for the entire surveyed population was 4.7 points. Exceeding the average level of listener satisfaction is noted for such criteria as satisfaction with the organization of events, satisfaction with the quality of the coaching (expert) composition of events, assessment of the overall level of organization of program events -4.9 points on a five-point scale, respectively; assessing the quality of the program events, assessing the level of accessibility of information on the implementation of the activities of the program "You are an Entrepreneur" - 4.8 points on a five-point scale, respectively.

Compliance with the average value of the level of satisfaction of students is noted by such criteria as satisfaction with the work of teachers, overall satisfaction from information, knowledge gained from participating in events 4.7 points on a five-point scale, respectively. 
Among the evaluations that the program participants made according to different evaluation criteria, a value less than the average for the whole surveyed population is noted for such criteria as an assessment of the level of information structure (4.5 points on a five-point scale) and an assessment of the applicability of new skills (4.0 points for five-point scale).

Thus, we can say that with an overall high positive assessment of activities, an essential area for improvement is to increase the applicability of the acquired entrepreneurial competencies and the quality of the content and methodological base of classes.

\section{DISCUSSION}

Among the current trends in training personnel in the higher education system in Russia and in the world are digitalization of the educational environment, practiceoriented systemic training, project and game development skills, polyprofessional competencies of the graduate.

Consideration of the scientific community discussion allows us to understand the definitions of these processes and the factors that determine them.

The development of the polyprofessional nature of a modern university graduate based on augmented entrepreneurial competence in technological education is gaining relevance in the activities of enterprises and organizations. A study of the authors Deligianni I., Voudouris I., Spanos Y., Lioukas S. presents the results of a study of the impact of technological and entrepreneurial competence on product innovation using the example of 100 successful companies developing new technologies [4]. The stability of their development and the success of the reaction to unforeseen circumstances, according to the authors, depended on the optimal combination of entrepreneurial and technological competencies of employees [11].

The authors of the study "Entrepreneurial Competences of University Students in the Digital Age: A Scale Development Study" Tekin M., Baş D., Geçkil T., Koyuncuoğlu Ö. [2] emphasize that new technological developments, gaining momentum with the 4-th industrial revolution, have a significant impact on the labor market. The introduction of new technologies can adversely affect some sectors of the economy and cause unemployment. To mitigate the negative consequences of this process, it is necessary for students at the university today to expand entrepreneurial competencies. They will subsequently contribute to the successful adaptation of graduates in the labor market.

In turn, according to researchers Tekin M., Koyuncuoğlu Ö., Geçkil T., Baş D. universities in format 4.0 should also be prepared for the new needs of enterprises and organizations in the competencies of specialists. We are talking not only about higher education programs, but also additional professional education - advanced training and retraining. One of the important trends in the higher education system of Turkey, which is maintained at the level of state power, is the maximum inclusion of entrepreneurial competencies in the training structure of a modern university graduate [1]. The importance of combining technological and entrepreneurial competencies in training programs for technologists of different profiles is convincingly proved by researchers $[5,6$, 7].

The study of Krajger I., Lattacher W., Schwarz E.J. is devoted to methodological approaches and educational technologies for the successful development of entrepreneurial competencies [3]. The authors note that the intensity of the development of the game approach aimed at the formation of entrepreneurial competencies of students does not correspond to the high level of relevance of this issue. In this regard, they studied and presented in the publication the results of a study of the factors for the successful implementation of the game method in teaching entrepreneurship. Among these factors we named: student satisfaction with the interaction with the teacher; game session structure; level of interest in the content of the game and the game result. The given example of educational practice contributes both to the development of the game method and to the improvement of the quality of entrepreneurial competencies of students, which is confirmed by a number of studies [8].

Saxena G. came to the conclusion (based on an online survey of 400 Indian social entrepreneurs) that it is necessary to develop entrepreneurial competencies among the leaders of social organizations in the non-profit sector [9]. In his opinion, the emerging trend of higher education is relevant not only for India, but also for other regions of the world. Thus, the focus of the polyprofessional trend on entrepreneurial competencies in training personnel for different sectors of the economy and manufacturing sectors is confirmed. [12].

In teaching entrepreneurship, an important additional effect is observed - entrepreneurial competence has a significant impact on the formation of positive psychological capital of students and successful teamwork in the organization $[10,13,15]$. A comparative study was conducted not only among students who studied entrepreneurship in addition to the main educational profile, but also among graduates who have their own small business [10].

Thus, the scientific discussion of representatives of different regions of the world confirms the presence and relevance of the educational trend - achieving the polyprofessionality of the future personnel through the development of entrepreneurial competencies.

\section{CONCLUSION}

A study of the process of achieving the polyprofessional future personnel through the development of entrepreneurial competencies allows us to draw a number of conclusions.

Firstly, the optimal combination of entrepreneurial and technological competencies of employees positively affects the development of innovative products of the enterprise and increases their stability under the conditions of uncertainty.

Secondly, entrepreneurial competencies are important for employees and managers of social organizations and the public sector.

Thirdly, in training the entrepreneurship, an important additional effect is observed - entrepreneurial competence has 
a significant impact on the formation of a positive psychological capital for graduates of educational programs of higher and additional professional education and contributes to successful team work in the organization.

Fourthly, on the basis of empirical research, the directions of improving the educational practices of forming entrepreneurial competencies are identified: expanding the gamification of educational activities; increasing student satisfaction with the teacher; optimization of the structure of game modules; the approximation of the content of the game to the real regional socio-economic conditions; increasing the educational motivation of project participants.

\section{References}

[1] M. Tekin, Ö. Koyuncuoğlu, T. Geçkil, D. Baş, "Evaluation of entrepreneurial-innovative university conditions and activities from students' point of view in the context of industry 4.0," in Lecture Notes in Mechanical Engineeringc, 2020, pp. 605-618.

[2] M. Tekin, D. Baş, T. Geçkil, Ö. Koyuncuoğlu, "Entrepreneurial competences of university students in the digital age: a scale development study," in Lecture Notes in Mechanical Engineeringc, 2020, pp. 593-604.

[3] I. Krajger, W. Lattacher, E.J. Schwarz, "Creating and testing a gamebased entrepreneurship education approach," in Advances in Intelligent Systems and Computing, 2020, pp. 697-709.

[4] I. Deligianni, I. Voudouris, Y. Spanos, S. Lioukas, "Non-linear effects of technological competence on product innovation in new technologybased firms: Resource orchestration and the role of the entrepreneur's political competence and prior start-up experience," in Technovation, vol. 88, 2019, 102076.

[5] E.S. Rahayu, M. Rahayuningsih, V. Noekent, A.R. Al Muhammady, "Developing entrepreneurial competencies of biology study program students through a business unit on plant tissue culture training," in Journal of Physics: Conference Series, vol. 1321(3), 2019, 032041.

[6] M.J. Beltrán Hernández de Galindo, L.M. Romero-Rodriguez, M.S. Ramirez Montoya, "Entrepreneurship competencies in energy sustainability MOOCs," in Journal of Entrepreneurship in Emerging Economies, vol. 11(4), 2019, pp. 598-616.

[7] A. Gustomo, A. Ghina, G. Anggadwita, S. Herliana, "Exploring entrepreneurial competencies in identifying ideas and opportunities, managing resources, and taking action: evidence from small catering business owners in Bandung, Indonesia," in Journal of Foodservice Business Research, vol. 22(6), 2019, pp. 509-528.

[8] F. Grivokostopoulou, K. Kovas, I. Perikos, "Examining the impact of a gamified entrepreneurship education framework in higher education," in Sustainability, Switzerland, vol. 11(20), 2019, 5623.

[9] G. Saxena, "Multidimensional competency construct for social entrepreneurs: a logistic regression approach," in Kasetsart Journal of Social Sciences, vol. 40(3), 2019, pp. 684-688.

[10] M. Hasan, S. Hatidja, Nurjanna, Gempita, M.I. Ma'ruf, "Entrepreneurship learning, positive psychological capital and entrepreneur competence of students: a research study," in Entrepreneurship and Sustainability Issues, vol. 7(1), 2019, pp. 425-437.

[11] M. Zarefard, D.-Y. Jeong, "The influence of entrepreneurial competencies of project leader on innovative idea generation in the ict firms," in Journal of Theoretical and Applied Information Technology, vol. 97(17), 2019, pp. 4612-4622.

[12] S.-M. Wang, H.-P. Yueh, P.-C. Wen, "How the new type of entrepreneurship education complements the traditional one in developing entrepreneurial competencies and intention," in Frontiers in Psychology, vol. 10,2019, pp. 20-48.

[13] S.C. Santos, M.H. Morris, A. Caetano, S.F. Costa, X. Neumeyer, "Team entrepreneurial competence: multilevel effects on individual cognitive strategies," in International Journal of Entrepreneurial Behaviour and Research, vol. 25(6), 2019, pp. 1259-1282.

[14] G. I. Idrissov, V. N. Knyaginin, A. L. Kudrin, E. S. Rozhkova, "New technological revolution: challenges and opportunities for Russia," in Economic Issues, vol. 4, 2018, pp. 5-25.

[15] M.A. Shadrina, N.N. Shelemekh, V.V. Mizyureva, V.E.O. Kerimov, B.V. Lukyanov, "The recognition and valuation of an asset's productivity in business accounting and reporting," in European Research Studies Journal, vol. 21 (4), 2018, pp. 129-141. 